\title{
Authenticity markers in habanero pepper (Capsicum chinense) by the quantification of mineral multielements through ICP-spectroscopy
}

\author{
Manuel Octavio RAMÍREZ-SUCRE ${ }^{1 \dagger}$ (D), Julio Enrique ONEY-MONTALVO ${ }^{1 \dagger}$ (D), Mariela Carolina LOPE-NAVARRETE ${ }^{2}$ (D), \\ Jesús Alberto BARRON-ZAMBRANO² (D), José Andrés HERRERA-CORREDOR ${ }^{3}$ (D), Adán CABAL-PRIETO ${ }^{4}$ (D), Ingrid \\ Mayanin RODRÍGUEZ-BUENFIL ${ }^{1 *}$ (D), Emmanuel de Jesús RAMÍREZ-RIVERA ${ }^{1,5 *}$ (D)
}

\begin{abstract}
The aim of this work was to determine in Capsicum chinense the 1) concentration of heavy metals ( $\mathrm{Al}, \mathrm{As}, \mathrm{Cd}, \mathrm{Pb}), \mathrm{majority}$ $(\mathrm{Ca}, \mathrm{K}, \mathrm{Mg}, \mathrm{Na})$ and essential ( $\mathrm{Cu}, \mathrm{Fe}, \mathrm{Mn}, \mathrm{Se}, \mathrm{Zn})$ mineral elements, 2) effects of ripening stage, harvest number and type of soil on the mineral content and 3) authenticity markers. Peppers grown in black and red soils of this Mayan region, were harvested in two ripening stages (ripe and ripening peppers [orange and green peppers, respectivily]) and in four post-transplant dates: I (132 post-transplant days, PTD), II (160PTD), III (209PTD) and IV (265PTD). These samples were analyzed by ICPSpectroscopy. The ripening stage affected the $\mathrm{Al}, \mathrm{Cu}$ and $\mathrm{Zn}$ contents in ripe peppers while As presented the highest content in ripening peppers. Harvests I y III presented the highest $\mathrm{Al}, \mathrm{Ca}, \mathrm{K}$ contents while harvests II y III presented the highest $\mathrm{As}$ and $\mathrm{Pb}$ contents. Nine and ten elements developed authenticity markers according to the maturation and harvest number, respectively. The results obtained will help the producers and industrialists to focused on the production and agronomic management of high quality habanero peppers.
\end{abstract}

Keywords: heavy metals; ICP-Spectroscopy; minerals; ripening state; type of soil.

Practical Application: Know the mineral concentration of the habanero pepper and its relationship with the maturation, number of cultivation and type of soil.

\section{Introduction}

Chili peppers are considered an important ingredient for gastronomy worldwide due to its sensory properties that influence the acceptance by consumers (Guzmán \& Bosland, 2017; SolleiroRebolledo \& Mejía-Chávez, 2018). These fruits contain different bio-functional compounds (e.g., capsaicinoids, vitamins A, E and $\mathrm{C}$ and carotenoids) and antioxidants (e.g. catechin, quercetin and kaempferol) that help preventing cardiovascular diseases, cancer and neurological disorders (Guzmán \& Bosland, 2017; Rodríguez-Buenfil et al., 2020). In Mexico, the production of chili peppers contributes with $20.2 \%$ of the national vegetables production, reporting more than 3 million ton of chili peppers in 2019 and a productive area of 147,000 ha destined for planting/ harvesting a vast variety of chili peppers (e.g. serrano, de arbol, jalapeno, guajillo, pasilla, ancho, piquin, manzano and habanero) (Servicio de Información Agroalimentaria y Pesquera, 2020). In Mexico the production of habanero pepper (Capsicum chinense Jacq.) reached 20,829.61 tons in 2019, while in the Yucatan region was of 6,287.70 tons in the same year (Oney-
Montalvo et al., 2020). An $80 \%$ of the production of habanero pepper is consumed fresh and the rest is used in the preparation of ancestral mayan foods and sauces (Castillejos-Alegría \& Porte-Morales 1997). Furthermore, habanero pepper has the distinction of Denomination of Origin (DO) associated with a specific Official Mexican Standard (NOM-189-SCFI) (Mexico, 2017) where its characteristics are state. Due to its economical and social importance, it is necessary to quantify the content of mineral multi-elements in habanero pepper to verify its safety and quality (Herman-Lara et al., 2019). In this sense, the habanero chili with DO is grown mainly in two types of soils in Yucatan, the Box lu'um (black soil) and K'áankab lu'um (red soil), these correspond to the mayan language names (Rodríguez Buenfil et al., 2020). However, there are other factors of great importance such as temperature, humidity, harvest number and ripening that may contribute to changes in the concentration of some mineral elements (e. g., Ca, K, Mg, Na, Cu, Cr, Mn, Se and $\mathrm{Zn}$ ) necessary for the correct metabolic functioning of the human being (Sevgi-Kirdar et al., 2015). From the point of view

\footnotetext{
$\dagger$ First author

Received 16 Apr., 2021

Accepted 10 June, 2021

${ }^{1}$ Centro de Investigación y Asistencia en Tecnología y Diseño del Estado de Jalisco A.C, Sede Sureste, Mérida, YN, México

${ }^{2}$ Facultad de Ingeniería Química, Universidad Autónoma de Yucatán, Mérida, YN, México

${ }^{3}$ Colegio de Postgraduados, Campus Córdoba, Veracruz, VZ, México

${ }^{4}$ Tecnológico Nacional de México, Campus Huatusco, Huatusco, VZ, México

${ }^{5}$ Tecnológico Nacional de México, Campus Zongolica, Zongolica, VZ, México

*Corresponding authors: irodriguez@ciatej.mx, ejramirezrivera@itszongolica.edu.mx
} 
of consumer protection, it is critical to know the concentration of heavy metals (e.g., $\mathrm{Al}, \mathrm{As}, \mathrm{Cd}$ and $\mathrm{Pb}$ ) that may be present in habanero pepper, to find strategies to minimize them and largely avoid clinical conditions such as cardiovascular toxicity, instability of the central nervous system, neurological problems, among others (Herman-Lara et al., 2019). Currently, the accumulation of heavy metals in soils is a cause for concern in agricultural production due to adverse effects (e.g., poor harvest and crop development) on food safety and consequently to the market economical behavior (Nagajyoti et al., 2010; Khanlari \& Jalali 2008). The identification of authenticity markers is currently carried out determining mineral elements of peppers produced in given regions as Tenerife in Spain or Oaxaca in Mexico, differentiating them from other similar peppers grown in other regions of the world (Herman-Lara et al., 2019). The currently research has been developed on the content of mineral elements in peppers focused on macro and microelements considering only the ripening state or the time of harvest (Rubio et al., 2002; PérezLópez et al., 2007; Khan et al., 2019). The effects of two heavy elements, Se and Al, have been analyzed in isolation to determine its influence on the human body as well as tolerance and toxicity levels in plants used for human consumption (Navarro-Alarcon \& Cabrera-Vique, 2008; Nagajyoti et al., 2010; He et al., 2019). Currently there is no scientific evidence on the behavior of the concentration of heavy, macro, and micro mineral elements based on factors as harvest number and type of soil related to the ripening state; this understanding could be helpful in the cultivation of habanero pepper. The aforementioned factors have been studied from the instrumental perspective of color (Ramírez-Sucre et al., 2018), carotenoid content (ZamaconaRuiz et al., 2018), volatile compounds and antioxidant activity (Gómez-Rincón et al., 2018). For all the above, the objective of this work was to determine the authenticity markers in habanero peppers (Capsicum chinense) by means of plasm atomic emission spectroscopy depending on the state of maturation, harvest number and soil type.

\section{Materials and methods}

\subsection{Obtaining samples of habanero pepper}

Samples of habanero peppers were obtained from plants grown in greenhouses of the Centro de Investigación y Asistencia en Tecnología y Diseño del Estado de Jalisco, A.C (CIATEJ) Southeast Unit. Three hundred seedlings of Capsicum chinense Jacq of 40 days of germination were acquired from a certified local supplier. The seedlings were transplanted to containers with $12 \mathrm{~kg}$ of black (Box lu'um) and red (K'áankab lu'um) soils. These two soils indicated that, red soil has the highest concentration of calcium $(2075.28 \pm 29.70 \mathrm{mg} / \mathrm{kg})$, magnesium $(779.23 \pm 12.71$ $\mathrm{mg} / \mathrm{kg})$, phosphorus $(11.00 \pm 2.38 \mathrm{mg} / \mathrm{kg})$ and iron $(6.27 \pm 0.21$ $\mathrm{mg} / \mathrm{kg})$, but the lowest concentration of organic matter $(5.16 \pm$ $0.04 \%$ ) (Oney-Montalvo et al., 2020). On the other hand, the black soil is characterized by having the highest concentration of nitrogen $(52.01 \pm 7.05 \mathrm{mg} / \mathrm{kg})$, manganese $(5.24 \pm 0.45 \mathrm{mg} / \mathrm{kg})$, organic matter $(10.93 \pm 0.23 \%)$ and the best electric conductivity $(2.32 \pm 0.16 \mathrm{~d} \mathrm{~S} / \mathrm{m})$. The crop was established in March 2018 in a white Gothic greenhouse with 2 ogival arches of polyethylene mesh (measurements: $26^{\star} 12^{\star} 7 \mathrm{~m}\left[\mathrm{~L}^{\star} \mathrm{a}^{\star} \mathrm{h}\right]$ ) with 5 beds $\left(1^{\star} 24 \mathrm{~m}\right)$.
The plants were irrigated every 3 days with water from a local well (electrical conductivity of the water oscillated from 2.8 to $3.4 \mathrm{mS}$.). The environmental conditions in the greenhouse were a relative humidity $(\mathrm{RH})>91 \%$ and temperatures between 24 and $47^{\circ} \mathrm{C}$. Habanero peppers cultivated in black and red soils (type of soil where it was cultivated), ripening (green coloration) and ripe (orange coloration) peppers (ripening stage) and harvested four times over 6 months (from july to December, every 2 moths approximately) with 132, 160, 209 and 265 post-transplant days (PTD) (number of harvests corresponding to harvests I, II, III, and IV) were selected to reach a total of 16 samples of chili peppers. The number of samples analyzed was similar to other investigations focused on the determination of content of multielements and authenticity markers in DO or regional products (Ibrahim \& Mehanna, 2015; Herman-Lara et al., 2019).

\subsection{Conditioning samples for mineral determination}

The conditioning of the samples was carried out in three successive stages: 1) A paste made from mechanically crushed Habanero peppers was frozen to $-50{ }^{\circ} \mathrm{C}$ for $24 \mathrm{~h}$. Subsequently, dehydration was performed by lyophilization (FreeZone6 Liter Benchtop, Labconco, USA) under operating conditions of -50 ${ }^{\circ} \mathrm{C}$ with a pressure of $0.200 \mathrm{mbar}$ for a period of $72 \mathrm{~h}$ according to Zamacona-Ruiz et al. (2018); 2) these samples were calcined at $550{ }^{\circ} \mathrm{C}$ for $5 \mathrm{~h}$ in a muffle (Felisa, FE-340, Feligneo, Mexico) according to method 935.42 of the Association of Official Analytical Chemists (2012); 3) finally, $0.025 \mathrm{~g}$ of ashes were taken from each sample and dissolved in $10 \mathrm{~mL}$ of a mixture ( $1: 2 \mathrm{v} / \mathrm{v}$ ratio) of $\mathrm{HCl}$ and $\mathrm{HNO}_{3}$ (Merck, Darmstadt, Germany) in a volumetric flask and finally adjusted to $50 \mathrm{~mL}$ with ultra high purity water (Pérez-López et al., 2007).

\subsection{Analytical processing}

The concentrations of the: 1) heavy metals as aluminum $(\mathrm{Al})$, arsenic (As), cadmium $(\mathrm{Cd})$, and lead $(\mathrm{Pb}), 2)$ majority elements as calcium $(\mathrm{Ca})$, potassium $(\mathrm{K})$, magnesium $(\mathrm{Mg})$ and sodium $(\mathrm{Na})$ and 3 ) essential elements as copper $(\mathrm{Cu})$, iron $(\mathrm{Fe})$, manganese $(\mathrm{Mn})$, selenium $(\mathrm{Se})$, and zinc $(\mathrm{Zn})$, were quantified using a microwave induced Plasm Atomic Emission Spectroscopy (MP-AES, 4200MP-AES, Agilent Technologies, New Castle, Delawere, USA) connected to a nitrogen generator (Peak Genius 3055, Agilent Technologies, New Castle, Delawere, USA). The operating conditions (nebulizer flow and wavelength per element) of the MP-AES equipment were previously stablished by Herman-Lara et al. (2019). All multielement solutions were diluted in a range of concentrations of $0.1-5 \mathrm{mg} / \mathrm{L}$. The calibration curves (coefficient of correlation $R^{2}=0.99$ per element) using multielement standard solutions (Agilent Technologies, Delawere, USA) were carried out for $\mathrm{Al}, \mathrm{As}, \mathrm{Cd}, \mathrm{Cu}, \mathrm{Mn}, \mathrm{Pb}$, Se, and $\mathrm{Zn}(50$ $\mathrm{mg} / \mathrm{L})$ and $\mathrm{Ca}, \mathrm{K}, \mathrm{Mg}$, and $\mathrm{Na}(500 \mathrm{mg} / \mathrm{L})$. The determinations were carried out six times for reproducible and reliable results (Herman-Lara et al., 2019).

\subsection{Statistical analysis}

The sampling was carried out by the split-split plot design reported by Oney-Montalvo et al. (2021). During the four 
harvesting periods samples of the same plants were taken, and three replications were analyzed by each combination of soil, maturity stage and harvest date. The data analysis strategy consisted of three phases. Phase 1) application of a variance analysis model (ANOVA) to a factor (sample) with $\alpha=0.05$ and a Tukey post hoc test to determine significant difference based on the content of the elements. Phase 2) application of a three-way model (ripening state, harvest number and type of soil) analysis of variance (ANOVA) to determine the importance of the factors and their influence on the content of mineral multi-elements. Phase 3) determination of authenticity markers according to the most influential factors (significant effect $p<$ 0.05 ) obtained in phase 2 . Heavy elements were also considered as part of the analysis of authenticity markers of habanero pepper since they have critical relevance due to health implications in other products such as wine and cheese (Wadood et al., 2020; Herman-Lara et al., 2019). For this purpose, a Discriminat Analysis (DA) stepwise procedure was used (Flores et al., 2013; Chávez-Servia et al., 2016). In addition, the following statistical indicators derived stepwise, were interpreted: A) Wilk's Lambda test $(\lambda)$ and probability values $(p)$ to determine the significance of discriminant functions was applied (Shintu \& Caldarelli, 2006); B) the distances of Mahalanobis and confidence ellipses with a confidence level of $95 \%$ were used to determine the separation of the sample of habanero pepper (according to most factors with significant effect obtained in phase 2) in the factorial plane of the DA and C) the percentage (\%) of classification was applied to check the discriminatory capacity of the model generated based on the content of elements (Moreno-Rojas et al., 2010; Wadood et al., 2020). All statistical tests were performed with the software STATGRAPHIC PLUS ${ }^{\circ}$ version 5.2 (Statistical Graphics Corp, U.S.A).

\section{Results}

\subsection{Phase I: analysis of the content of heavy, major and minor elements}

The results per mineral element are shown in Table 1. It is observed that all the elements exhibited significant differences $(p$ $<0.05$ ) according to their content, except for Cd (undetectable). Concentrations of the hevay metals $\mathrm{Al}$, As and $\mathrm{Pb}$ ranged from

Table 1. Average concentration (ppm) of each mineral element analyzed for the different samples of habanero pepper.

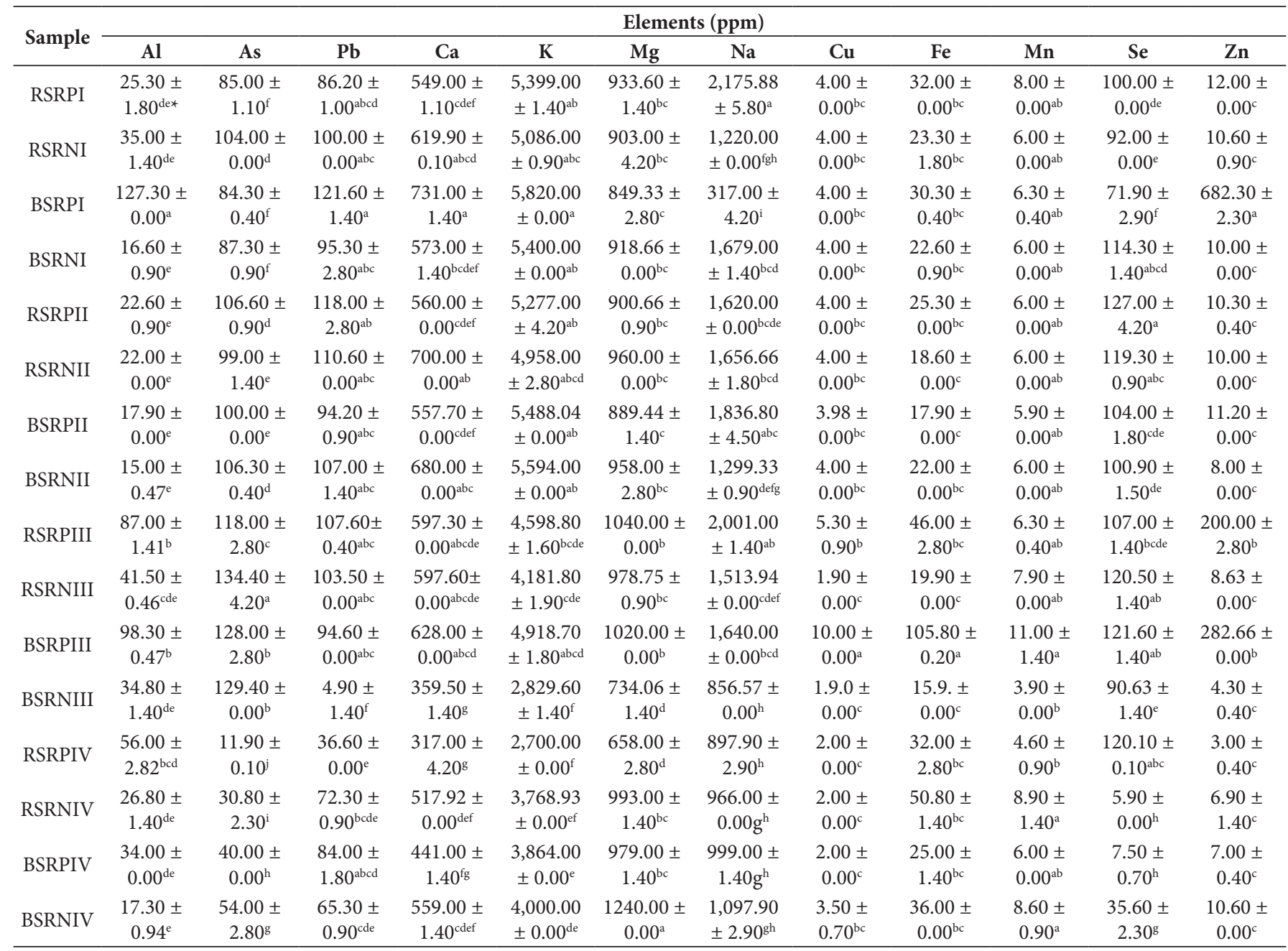

${ }^{\star}$ Different literals in columns indicates significant difference according to Tukey test at $p<0.05$; BS = Black soil (mayan name: Box lu'um); RS = Red soil (mayan name: K'áankab lu’um); RN = is ripening habanero pepper of green coloration; RP = is ripe habanero pepper of orange coloration; Numbers I, II, III and IV indicate the harvests that correspond to 132, 160, 209 and 265 PTD. 
15-127.3; 30.8-134.4 and 4.9-121.6 ppm, respectively; while concentrations of the major elements $\mathrm{Ca}, \mathrm{Mg}, \mathrm{K}$ and $\mathrm{Na}$ were quantified between $317-731$; 734-1240; 2700-5820 and 317-2175 ppm, respectively. The concentrations of the minor elements $\mathrm{Cu}$, $\mathrm{Fe}, \mathrm{Mn}$, Se and $\mathrm{Zn}$ were in the ranges $1.9-10 ; 17.9-105.8 ; 3.9-11$; 5.9-127; 3-682.33 ppm, respectively.

\subsection{Phase II: effect of ripening, harvest number and type of soil in the concentration of multi-elements}

Table 2 shows the results of probability obtained for the factors ripening stage, harvest number and type of soil. It is observed that ripening stage was significant in the mineral

Table 2. Probability values of the analysis of variance (ANOVA) to three factors (ripening, harvest number and type of soil).

\begin{tabular}{|c|c|c|c|}
\hline Element & Ripening & Harvest number & Type of soil \\
\hline \multicolumn{4}{|l|}{ Heavy } \\
\hline $\mathrm{Al}$ & $0.0008^{* * *}$ & $0.004^{\star *}$ & $0.51^{\mathrm{ns}}$ \\
\hline As & $0.007^{\star \star}$ & $<0.001^{\star *}$ & $0.12^{\text {ns }}$ \\
\hline $\mathrm{Cd}$ & $0.32^{\mathrm{ns}}$ & $0.4^{\mathrm{ns}}$ & $0.32^{\mathrm{ns}}$ \\
\hline $\mathrm{Pb}$ & $0.25^{\mathrm{ns}}$ & $0.008^{\star *}$ & $0.35^{\mathrm{ns}}$ \\
\hline \multicolumn{4}{|c|}{ Major } \\
\hline $\mathrm{Ca}$ & $0.40^{\mathrm{ns}}$ & $0.004^{* *}$ & $0.79^{\text {ns }}$ \\
\hline $\mathrm{K}$ & $0.14^{\mathrm{ns}}$ & $<0.0001^{\star *}$ & $0.20^{\mathrm{ns}}$ \\
\hline $\mathrm{Mg}$ & $0.27^{\mathrm{ns}}$ & $0.78^{\mathrm{ns}}$ & $0.55^{\mathrm{ns}}$ \\
\hline $\mathrm{Na}$ & $0.32^{\mathrm{ns}}$ & $0.03^{\star}$ & $0.06^{\mathrm{ns}}$ \\
\hline \multicolumn{4}{|c|}{ Essential } \\
\hline $\mathrm{Cu}$ & $0.049^{*}$ & $0.05^{\mathrm{ns}}$ & $0.20^{\mathrm{ns}}$ \\
\hline $\mathrm{Fe}$ & $0.06^{\mathrm{ns}}$ & $0.06^{\mathrm{ns}}$ & $0.61^{\mathrm{ns}}$ \\
\hline $\mathrm{Mn}$ & $0.89^{\text {ns }}$ & $0.50^{\text {ns }}$ & $0.99^{\text {ns }}$ \\
\hline $\mathrm{Se}$ & $0.29^{\mathrm{ns}}$ & $<0.0001^{\star *}$ & $0.06^{\mathrm{ns}}$ \\
\hline $\mathrm{Zn}$ & $0.01^{* *}$ & $0.06^{\mathrm{ns}}$ & $0.08^{\mathrm{ns}}$ \\
\hline
\end{tabular}

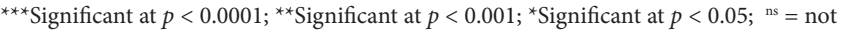
significant. elements $\mathrm{Al}, \mathrm{As}, \mathrm{Cu}$ and $\mathrm{Zn}$; while harvest number influences the concentration of the elements $\mathrm{Al}, \mathrm{As}, \mathrm{Pb}, \mathrm{Ca}, \mathrm{K}, \mathrm{Na}$ and $\mathrm{Se}$. In Table 3 the average results of each mineral element analyzed are shown. The ripening factor demonstrated the existence of significant differences $(p<0.001)$ in heavy metals (Al and As) as well as in minority elements ( $\mathrm{Cu}$ and $\mathrm{Zn}$ ); the ripening peppers obtained a higher concentration of $\mathrm{Al} 58.57 \pm 39.6, \mathrm{Cu} 4.41 \pm$ 2.4 and $\mathrm{Zn} 151.07 \pm 36.70$ ppm (Table 3), respectively. Only As presented the highest content in ripening peppers $93.18 \pm 32.2$ compared to ripe peppers $84.23 \pm 38.30 \mathrm{ppm}$ (Table 3 ). For the harvest number factor, significant differences $(p<0.05)$ were found in heavy metals ( $\mathrm{Al}, \mathrm{As}$ and $\mathrm{Pb}$ ), in the major elements $(\mathrm{Ca}, \mathrm{K}$ and $\mathrm{Na}$ ) and in the minor mineral element Se. The highest contents of the heavy mineral elements $\mathrm{Al}(65.42 \pm 29.55$ ppm) and As (127.48 $\pm 6.75 \mathrm{ppm})$ were found in harvest III; in contrast, for $\mathrm{Pb}$ was found in harvest II (107.48 $\pm 9.2 \mathrm{ppm})$ (Table 3 ). The highest concentrations of the major elements $\mathrm{Ca}$ and Na were obtained in harvest II (624.42 \pm 70.49 and 1603.20 $\pm 207.05 \mathrm{ppm}$, respectively) while in the case of $\mathrm{K}$ the highest concentrations were observed in harvest I $(5,426.25 \pm 278.89$ ppm) and II (5,329.26 $\pm 259.60 \mathrm{ppm})$ with a subsequent decrease (Table 3 ) due to an expected effect of the $\mathrm{K}$ depletion in soils; $\mathrm{Mg}$ seems to accumulate until reaching a maximum content in harvest IV $(967.50 \pm 220.93 \mathrm{ppm})$. In the case of minority elements, Se exhibited the highest contents in harvest II and III $(112.8 \pm 11.6$ and $109.95 \pm 13.40$ ppm, respectively).

\subsection{Phase III: determination of authenticity markers according to the most influential factors}

The results of the determination of the authenticity markers according to the maturation stage and the harvest number factors show that for the maturation factor, the elements $\mathrm{As}, \mathrm{Pb}, \mathrm{Ca}, \mathrm{Na}, \mathrm{Cu}, \mathrm{Fe}, \mathrm{Mn}$, Se and $\mathrm{Zn}$ contributed to differentiate the peppers according to their ripening stage while the classification percentage of the model used

Table 3. Average concentrations (ppm) per mineral element according to the factors ripening, harvest number and type of soil.

\begin{tabular}{|c|c|c|c|c|c|c|c|c|}
\hline \multirow[b]{2}{*}{ Element } & \multicolumn{2}{|c|}{ Ripening stage } & \multicolumn{4}{|c|}{ Harvest (post-transplant days) } & \multicolumn{2}{|c|}{ Soil } \\
\hline & $\begin{array}{l}\text { Ripening (green } \\
\text { coloration) }\end{array}$ & $\begin{array}{l}\text { Ripe (orange } \\
\text { coloration) }\end{array}$ & I (132) & II (160) & III (209) & IV (265) & Black (Box lu’um) & $\begin{array}{c}\text { Red } \\
\text { (K'áankablu’um) }\end{array}$ \\
\hline \multicolumn{9}{|l|}{ Heavy } \\
\hline $\mathrm{Al}$ & $26.15 \pm 9.60^{\mathrm{b} *}$ & $58.57 \pm 39.60^{\mathrm{a}}$ & $51.08 \pm 47.50^{\mathrm{a}}$ & $19.39 \pm 3.35^{\mathrm{b}}$ & $65.42 \pm 29.55^{\mathrm{a}}$ & $33.55 \pm 15.27^{\mathrm{b}}$ & $45.18 \pm 41.70^{\mathrm{a}}$ & $39.54 \pm 21.60^{\mathrm{a}}$ \\
\hline As & $93.18 \pm 32.20^{\mathrm{a}}$ & $84.23 \pm 38.30^{\mathrm{b}}$ & $90.16 \pm 8.60^{c}$ & $103.00 \pm 3.82^{\mathrm{b}}$ & $127.48 \pm 6.75^{\mathrm{a}}$ & $34.19 \pm 16.39^{\mathrm{d}}$ & $91.18 \pm 30.90^{\mathrm{a}}$ & $86.23 \pm 41.30^{\mathrm{a}}$ \\
\hline $\mathrm{Cd}$ & $0.00 \pm 0.00^{\mathrm{a}}$ & $0.00 \pm 0.00^{\mathrm{a}}$ & $0.00 \pm 0.00^{\mathrm{a}}$ & $0.00 \pm 0.00^{\mathrm{a}}$ & $0.00 \pm 0.00^{\mathrm{a}}$ & $0.00 \pm 0.00^{\mathrm{a}}$ & $0.00 \pm 0.00^{\mathrm{a}}$ & $0.00 \pm 0.00^{\mathrm{a}}$ \\
\hline $\mathrm{Pb}$ & $82.40 \pm 34.10^{\mathrm{a}}$ & $92.90 \pm 25.70^{\mathrm{a}}$ & $100.80 \pm 13.90^{\mathrm{a}}$ & $107.48 \pm 9.20^{\mathrm{a}}$ & $77.72 \pm 45.10^{\mathrm{b}}$ & $64.59 \pm 18.60^{\mathrm{bc}}$ & $83.40 \pm 34.40^{\mathrm{a}}$ & $91.90 \pm 25.60^{\mathrm{a}}$ \\
\hline \multicolumn{9}{|l|}{ Major } \\
\hline $\mathrm{Ca}$ & $575.87 \pm 102.70^{\mathrm{a}}$ & $547.63 \pm 119.60^{\mathrm{a}}$ & $618.25 \pm 74.75^{\mathrm{a}}$ & $624.42 \pm 70.49^{\mathrm{a}}$ & $545.62 \pm 115.61^{\mathrm{a}}$ & $458.73 \pm 98.90^{\mathrm{b}}$ & $566.16 \pm 291.10^{\mathrm{a}}$ & $557.34 \pm 107.60^{\mathrm{a}}$ \\
\hline $\mathrm{K}$ & $4,477.31 \pm 911.50^{\mathrm{a}}$ & $4,758.19 \pm 995.10^{\mathrm{a}}$ & $5,426.25 \pm 278.89^{\mathrm{a}}$ & $5,329 \cdot 26 \pm 259.60^{\mathrm{a}}$ & $4,132.26 \pm 851.10^{\mathrm{b}}$ & $3,583.23 \pm 552.16^{\mathrm{b}}$ & $4,739.30 \pm 1025.40^{\mathrm{a}}$ & $4,496.20 \pm 883.20^{\mathrm{a}}$ \\
\hline $\mathrm{Mg}$ & $960.68 \pm 134.50^{\mathrm{a}}$ & $908.76 \pm 116.70^{\mathrm{a}}$ & $901.16 \pm 34.08^{\mathrm{a}}$ & $927.02 \pm 34.47^{\mathrm{a}}$ & $943.20 \pm 131.22^{\mathrm{a}}$ & $967.50 \pm 220.93^{\mathrm{a}}$ & $948.56 \pm 142.00^{\mathrm{a}}$ & $920.88 \pm 112.10^{\mathrm{a}}$ \\
\hline $\mathrm{Na}$ & $1,286.19 \pm 298.90^{\mathrm{a}}$ & $1,435.95 \pm 614.80^{\mathrm{a}}$ & $1,347.97 \pm 731.79^{\mathrm{a}}$ & $1,603.20 \pm 207.05^{\mathrm{a}}$ & $1,502.88 \pm 442.31^{\mathrm{a}}$ & $990.23 \pm 77.06^{\mathrm{b}}$ & $1215.70 \pm 487.80^{\mathrm{a}}$ & $1,506.44 \pm 443.10^{\mathrm{a}}$ \\
\hline \multicolumn{9}{|l|}{ Essential } \\
\hline $\mathrm{Cu}$ & $3.18 \pm 0.90^{\mathrm{b}}$ & $4.41 \pm 2.40^{\mathrm{a}}$ & $4.00 \pm 0.00^{\mathrm{a}}$ & $3.99 \pm 0.07^{\mathrm{a}}$ & $4.82 \pm 3.50^{\mathrm{a}}$ & $2.37 \pm 0.70^{\mathrm{b}}$ & $4.18 \pm 2.40^{\mathrm{a}}$ & $3.41 \pm 1.20^{\mathrm{a}}$ \\
\hline $\mathrm{Fe}$ & $26.16 \pm 11.20^{\mathrm{a}}$ & $39.29 \pm 27.10^{\mathrm{a}}$ & $27.08 \pm 4.40^{\mathrm{a}}$ & $20.98 \pm 3.10^{\mathrm{a}}$ & $46.91 \pm 38.30^{\mathrm{a}}$ & $35.94 \pm 10.10^{\mathrm{a}}$ & $34.45 \pm 28.50^{\mathrm{a}}$ & $31.00 \pm 11.50^{\mathrm{a}}$ \\
\hline $\mathrm{Mn}$ & $6.69 \pm 1.60^{\mathrm{a}}$ & $6.78 \pm 1.90^{\mathrm{a}}$ & $6.58 \pm 0.90^{\mathrm{a}}$ & $5.99 \pm 0.01^{\mathrm{a}}$ & $7.32 \pm 2.70^{\mathrm{a}}$ & $7.07 \pm 2.00^{\mathrm{a}}$ & $6.74 \pm 2.10^{\mathrm{a}}$ & $6.74 \pm 1.40^{\mathrm{a}}$ \\
\hline $\mathrm{Se}$ & $84.92 \pm 40.50^{\mathrm{a}}$ & $94.89 \pm 37.90^{\mathrm{a}}$ & $94.55 \pm 16.40^{\mathrm{a}}$ & $112.80 \pm 11.60^{\mathrm{a}}$ & $109.95 \pm 13.40^{\mathrm{a}}$ & $42.31 \pm 49.60^{\mathrm{b}}$ & $80.82 \pm 38.80^{\mathrm{a}}$ & $98.99 \pm 38.00^{\mathrm{a}}$ \\
\hline $\mathrm{Zn}$ & $8.65 \pm 2.17^{\mathrm{b}}$ & $151.07 \pm 36.70^{\mathrm{a}}$ & $178.75 \pm 51.89^{\mathrm{a}}$ & $9.90 \pm 1.20^{\mathrm{a}}$ & $123.90 \pm 51.89^{\mathrm{a}}$ & $6.91 \pm 2.90^{\mathrm{a}}$ & $127.03 \pm 36.70^{\mathrm{a}}$ & $32.70 \pm 36.70^{\mathrm{a}}$ \\
\hline
\end{tabular}

${ }^{*}$ Different literals in a row indicate significant differences by factor according to Tukey test at $p<0.05$. 

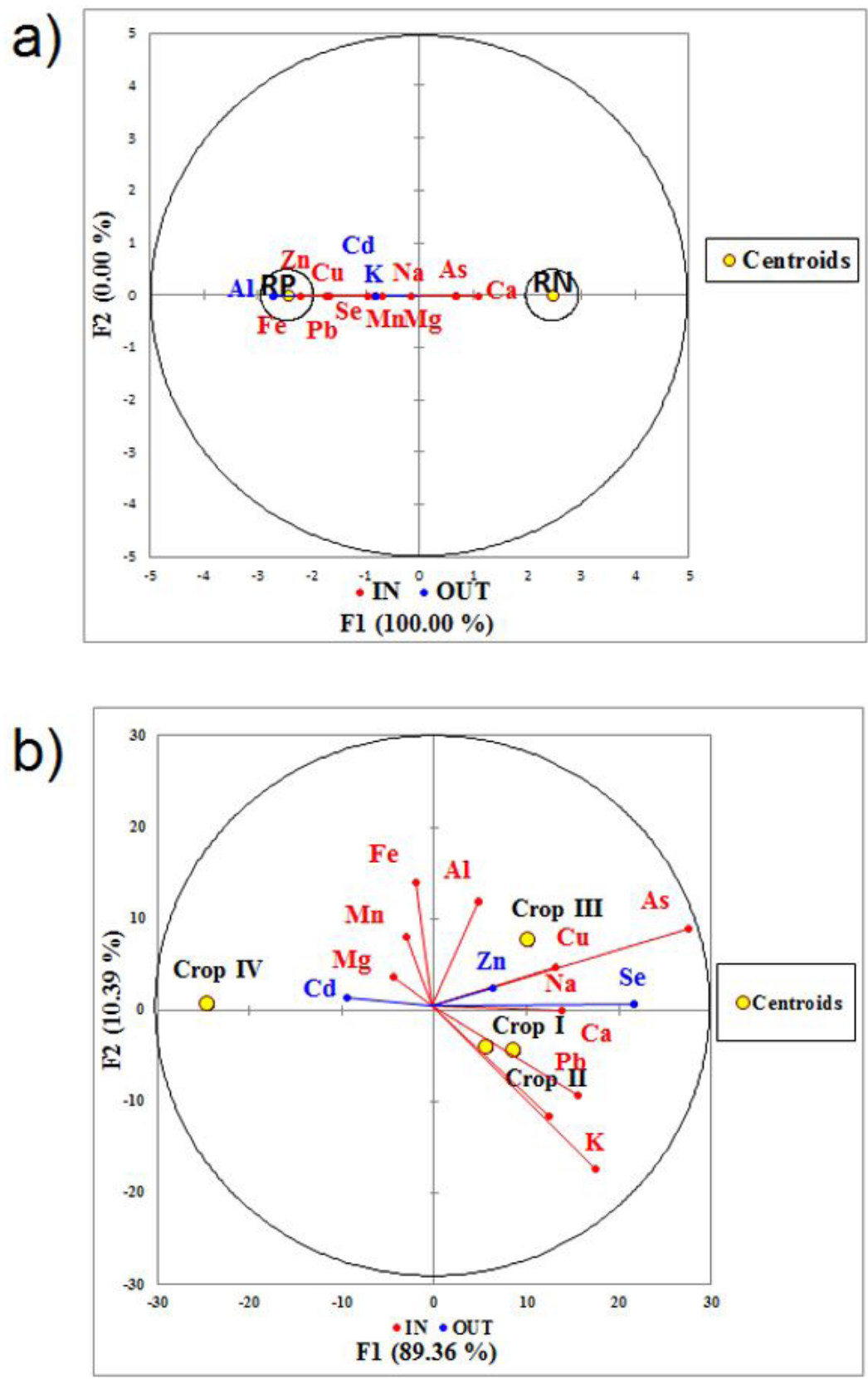

Figure 1. Discriminant analysis for the qualitative variable. (a) Ripening; (b) Crop number. Non-overlapping confidence ellipses (confidence level of 95\%) indicate differences between peppers. $\mathrm{RN}=$ ripening habanero pepper of green coloration; $\mathrm{RP}=$ ripe habanero pepper of orange coloration; IN = indicates that the element is considered within the discrimination model; OUT = indicates that the element is not considered within the discrimination model; Crops I, II, III and IV correspond to 32, 160, 209 and 265 PTD.

was $100 \%$. The discrimination between ripening and ripe peppers in the DA factorial space was determined by the distance of Mahalanobis $(24.17, p<0.0001)$. Figure 1a shows the first two discriminant functions ( $\lambda$ of Wilk's $=0.13, p$ $<0.0001$ ) that explain $100 \%$ of the data variation with only two components. In this sense, ripening peppers are related to the authenticity markers As and Ca while ripe peppers are related to the elements $\mathrm{Fe}, \mathrm{Cu}, \mathrm{Pb}, \mathrm{Se}, \mathrm{Mn}, \mathrm{Mg}, \mathrm{Na}$ and $\mathrm{Zn}$ (Figure 1a). In the case of the harvest number factor, only the elements $\mathrm{Al}, \mathrm{As}, \mathrm{Pb}, \mathrm{Ca}, \mathrm{K}, \mathrm{Mg}, \mathrm{Na}, \mathrm{Cu}, \mathrm{Fe}$ and $\mathrm{Mn}$ are considered as authenticity markers (Figure $1 \mathrm{~b}$ ), this constitutes the $76.92 \%$ of the mineral elements used. The percentage of discrimination of the model for the harvest number factor was $93.75 \%$. The different distances of Mahalanobis between chilis of harvests I and II $(13.20, p<0.001)$, I and III (156.14, $p<0.001)$, I and IV (939.19, $p<0.001)$, II and III (148.74, $p<0.001)$ and III and IV $(1250.09, p<0.001)$ are shown in Figure 1b. This shows that peppers from harvests II and III are related to the authenticity markers $\mathrm{Ca}, \mathrm{K}$ and $\mathrm{Pb}$. The peppers of harvest III are related to the elements $\mathrm{Al}, \mathrm{As}, \mathrm{Cu}$ and $\mathrm{Na}$ while the peppers of harvest IV are related to $\mathrm{Fe}$, $\mathrm{Mg}$ and $\mathrm{Mn}$. 


\section{Discussion}

\subsection{Phase I: analysis of the content of heavy, major and essential elements}

The non-detection of the Cd element could be since its concentration was below the previously established detection limits (Moreno-Rojas et al., 2010; Herman-Lara et al., 2019). The values found for the heavy elements exceeded the maximum permitted limits of 15, 0.2 and $0.5 \mathrm{ppm}(\mathrm{mg} / \mathrm{kg})$ for $\mathrm{Al}$, As and $\mathrm{Pb}$, respectively, indicated in the international standards CODEX-STAN 193 (Food and Agriculture Organization, 1995), Commission Regulation (EC)-1881 (European Union, 2006) and NOM-243-SSA1-2005 (México, 2010). The possible sources of this metal contamination in peppers may be due to 1) industrial waste and environmental pollution caused by the proximity to industries and communication routes (400 and $4,750 \mathrm{~m}$ aproximately far away from the highway and a chicken farm, respectively), 2) use of foliar fertilizers and pesticides used during the cultivation of habanero pepper, 3) natural sources as soils (Nagajyoti et al., 2010). It is currently estimated that environmentally, more than 1.5 million tons of $\mathrm{Pb}$ are used for different industrial applications where the concentrations of $\mathrm{Cd}$ and $\mathrm{As}$ in the environment and water range from 0.1 a 1.0 $\mathrm{mg} / \mathrm{kg}$ and 20 to $100 \mathrm{ng} / \mathrm{m}^{3}$, respectively (Tchounwou et al., 2012; Fischer, 2005; Herman-Lara et al., 2019). On the other hand, the habanero pepper plant can absorb those elements from the soil due to the use of foliar fertilizers and pesticides. Wang et al. (2017) and Elloumi et al. (2016) mentioned that heavy metal ions in soil-plant systems can enter the plant by the roots and accumulate, considering this as another source of contamination. In other studies, Komárek et al. (2013) and Hamzenejad-Taghlidabad \& Sepehr (2018) commented that high soil $\mathrm{pH}$ can also facilitate both, the absorption of metal cations in soils and the precipitation of heavy metals, which influences the uptake of heavy metals by plants. However, from the nutrimental point of view, Khan et al. (2019) commented that the consumption of habanero pepper can serve as a supplement for supplying major elements ( $\mathrm{Ca}, \mathrm{Mg}, \mathrm{K}$ and $\mathrm{Na}$ ) required in the daily diet since vegetables represent the main source of $\mathrm{Ca}$; although, its concentration varies from one vegetable to another. In this sense, Ca together with other compounds such as $\mathrm{Mg}$, Vitamin A, D and ascorbic acid are involved in bone formation (Fleck, 1976). Nevertheless, Mg participates in the release of parathyroid hormone, as a catalyst to convert vitamin D into an active state and is also an important cofactor for carrying out various enzymatic reactions considered of great importance for the generation of energy from Adenosine Triphosphate (ATP) (Elinge et al., 2012; Qin et al., 2017). On the other hand, the consumption of $\mathrm{K}$ can contribute to lower blood pressure and urinary excretion of calcium that may favor the risk of cardiovascular disease and the development of osteoporosis (Zou et al., 2015). Moreover, $\mathrm{Na}$ is an element that contributes to the regulation of body fluids and helps maintaining the electrical potential in the human body as well as the proper functioning of muscles and nerves (Elinge et al., 2012; Ikpeme et al., 2014).

The content of $\mathrm{Cu}, \mathrm{Fe}$ and $\mathrm{Mn}$ would be originated mainly because the pepper is exposed to the environment for a long time where these elements may precipitate (Khan et al., 2019). From the metabolic point of view, the mineral $\mathrm{Cu}$ is involved in the development of red blood cells, Fe absorption, glucose metabolism, cholesterol and protein and enzyme synthesis (Khan et al., 2019). Fe mineral element is associated with blood production and blood color and its deficiency is related to malnutrition in infants and pregnant women (Chávez-Servia et al., 2016). Element $\mathrm{Mn}$ is used in different physiological processes such as energy metabolism, antioxidant defense, immune function, among others (Materska \& Perucka, 2005). The Se mineral is an element that acts as a cofactor of various enzymes that protect from oxidative stress, whose antioxidant function can reduce the damage caused by ultraviolet- $\beta$ radiation in humans (Navarro-Alarcon \& Cabrera-Vique, 2008). Mineral element $\mathrm{Zn}$ is present in all body tissue, acts as an enzymatic cofactor of RNA polymerase, is essential for the immune system and plays a key role in numerous transcription factors (Nagajyoti et al., 2010). The concentrations of $\mathrm{Cu}, \mathrm{Fe}, \mathrm{Mn}, \mathrm{Zn}$ and $\mathrm{Ar}$ obtained in this work, would inform to consumers the daily needs of essential minerals covered when consuming the habanero pepper. In accordance with Rubio et al. (2002) and ChávezServia et al. (2016) 100 to $150 \mathrm{~g}$ of dry weight or 1.6 to $2.7 \mathrm{~g}$ of fresh chili pepper should be consumed daily to cover the daily nutritional requirements of the mineral elements mentioned above. Peppers are considered as an ingredient of potential use for the elaboration of diets in regions where the lack of other plant (e.g., nuts, lentils, chickpeas, cabbage) or animal origin sources is prominent, being highly recommended by nutritionists (Chávez-Servia et al., 2016). According to Institute of Medicine (US) Panel on Dietary Antioxidants and Related Compounds 2000, Bou-Khouzam et al. (2011) and Sevgi-Kirdar et al. (2015) a healthy adult requires an ingestion of 3-5, 8-15, 2-5, 11 and 0.055 $\mathrm{mg} /$ day of $\mathrm{Cu}, \mathrm{Fe}, \mathrm{Mn}, \mathrm{Zn}$ and Se, respectively. However, the differences found in heavy, major and minor metals considered in this research may be corrected by agricultural practices that involve the use of fertilizers, soil type, herbicide and pesticides (Sevgi-Kirdar et al., 2015; Khan et al., 2019).

\subsection{Phase II: effect of ripening, harvest number and type of soil in the concentration of multi-elements}

The significance of the ripening factor in the mineral content of peppers was also demonstrated by Rubio et al. (2002) who evaluated ripe peppers (Capsicum annuum) (red coloration) of the Island of Tenerife, Spain. These authors reported higher contents of $\mathrm{Cu}$ and $\mathrm{Zn}(0.7$ and $1.7 \mathrm{ppm}$, respectively) compared to ripening peppers (green coloration). For its part, Pérez-López et al. (2007) found low concentrations of $\mathrm{Cu}(2.2-4.4 \mathrm{ppm})$ and $\mathrm{Zn}(10.8-17.2 \mathrm{ppm})$ in ripe sweet peppers (Sweet Peppers, cv. Almuden) from Spain compared to ripening peppers $\mathrm{Cu}$ (3.3-11.7 ppm) and $\mathrm{Zn}(6.2-50.7 \mathrm{ppm})$. In the case of ripening pepper, the high concentrations of $\mathrm{Al}$ could be due to the accumulation of this element in the roots or in the cellular vacuoles of the plant (He et al., 2019). The high content of As in ripening peppers may be due to the fact that the environment becomes more alkaline due to the use of fertilizers that contributes to a decrease in the absorption of other heavy metals in the developing pepper (Nagajyoti et al., 2010). The ammounts of $\mathrm{Ca}, \mathrm{Na}, \mathrm{K}$ and $\mathrm{Mg}$ could be caused by a greater 
metabolic regulation of carbohydrates and proteins in the root of the plant (Wang et al., 2012). Navarro-Alarcon \& CabreraVique (2008) mentioned that differences in the concentrations of elements could be a result of the redox potential of the soil, the existence of some organic and inorganic compounds or to the climatic conditions that influence the distribution, condition and availability of the elements.

\subsection{Phase III: determination of authenticity markers according to the most influential factors}

The results obtained from the discriminant functions are consistent with those obtained by Chávez-Servia et al. (2016) who reported significance in the first two discriminant functions $(\lambda$ of Wilk's $=0.014$ and $p<0.01$ ) of DA for the analysis of peppers from the state of Oaxaca, Mexico. The mineral elements identified as authenticity markers found in the present work have also been reported by Qin et al. (2017) to the differentiation of spinach from Indian, Holland, Macedonia, Turkey, Afghanistan, Italy, China, Japan and Iran, this work reports the following elements $\mathrm{B}, \mathrm{Ca}, \mathrm{Co}$, $\mathrm{Cu}, \mathrm{Fe}, \mathrm{Mg}, \mathrm{Mn}, \mathrm{Mo}, \mathrm{Na}, \mathrm{Ni}, \mathrm{P}, \mathrm{S}$, and $\mathrm{Zn}$ as markers in vegetables. For its part, Flores et al. (2013) reported that the mineral elements $\mathrm{Cu}, \mathrm{K}, \mathrm{Mg}, \mathrm{Mn}$ and $\mathrm{Zn}$ were considered as authenticity markers of sweet peppers (Capsicum annum L.) from Spain, grown in organic, conventional and mixed systems. The percentages of classification obtained in this work were consistent with those obtained by Flores et al. (2013) and Chávez-Servia et al. (2016) who reported classification percentages of 90.4 and $91 \%$ in the differentiation of sweet peppers and native peppers, respectively, from the State of Oaxaca, Mexico. Although investigations related to the identification of authenticity markers of foods such as dairy products (Moreno-Rojas et al., 2010), peppers with DO or regional and local importance (Flores et al., 2013; Chávez-Servia et al., 2016; Qin et al., 2017; Mexico, 2017) do not consider heavy metals as part of authenticity markers in these final products. Moreover, the soil origin, agricultural techniques applied and tecnological procedures followed (Ionete et al., 2016) are related to the content of metals (including heavy metals) in fruits and vegetables. These elements should be included with the aim of seeking strategies that minimize its contents in food products and thereby improving the food quality and food safety of consumers (Wuana \& Okieimen, 2011).

\section{Conclusions}

The concentration of heavy metals in habanero pepper exceeded the limits allowed by official national and international standards. This allows to focus new research in determining the sources of pollution of habanero pepper by heavy metals. However, the found contents of macro and micro elements can contribute to reduce the deficit of these elements in the consumer's diet because they are nutritionally valuable and necessary for the organism. It is also concluded that ripening and harvest factors had an influence on the content of mineral elements in habanero peppers; where ripening peppers had the highest concentrations of $\mathrm{Al}, \mathrm{Cu}$ and $\mathrm{Zn}$ while $\mathrm{Ar}$ was presented with higher content in ripening peppers. Regarding the factor harvest number, it is concluded that at 132 PTD (harvest I) and 209 PTD (harvest III) the highest contents of $\mathrm{Al}, \mathrm{Ca}, \mathrm{K}$ were found while at 160 PTD (harvest II) and 209 PTD (harvest III) the highest $\mathrm{Ar}$ and $\mathrm{Pb}$ contents were observed. It was also observed that the mineral elements $\mathrm{Cu}$ and Se exhibited high concentrations in all harvests. Only the type of soil did not have a significant impact on any of the elements analyzed. Regarding the authenticity markers, nine elements $(\mathrm{As}, \mathrm{Pb}, \mathrm{Ca}, \mathrm{Na}, \mathrm{Cu}, \mathrm{Fe}, \mathrm{Mn}$, Se and $\mathrm{Zn}$ ) allow to differentiate the habanero peppers according to their ripening stage and ten elements $(\mathrm{Al}, \mathrm{As}, \mathrm{Pb}, \mathrm{Ca}, \mathrm{K}, \mathrm{Mg}$, $\mathrm{Na}, \mathrm{Cu}, \mathrm{Fe}$ and $\mathrm{Mn}$ ) were considered as authenticity markers based on the harvest number factor. This was confirmed with the discriminatory capacity of the applied model, with 100 and $93.75 \%$ for ripening stage and harvest number factors, respectively. The results obtained in the present work can be very useful for the producers and industrialists focused on the production of habanero peppers and as a reference for new investigations that need to evaluate other factors such as agronomic management, type of production, among others.

\section{Acknowledgements}

To Consejo Nacional de Ciencia y Tecnologia (CONACYT) of México for funding the postdoctoral fellowship awarded (2do año de continuidad de estancias posdoctorales vinculadas al fortalecimiento de la calidad del posgrado nacional 2019-2) to the first author for the realization of the project entitled "Validación de marcadores de autenticidad y su influencia en las emociones y la satisfacción de los consumidores de chile habanero (Capsicum chinense Jacq.) con denominación de origen de la Peninsula de Yucatán" and for founding the research project 257588 (SEP-CONACYT 2015) entitled "Análisis de los cambios metabolómicos durante el desarrollo del fruto Capsicum chinense Jacq cultivado en diferentes tipos de suelo". We thank Adriana García Hernández for her support in the preparation of the samples of habanero pepper.

\section{References}

Association of Official Analytical Chemists - AOAC. (2012). Official methods of analysis of the Association of Official Analytical Chemists: ash of cheese (Method 935.42). Gaithersburg: AOAC.

Bou-Khouzam, R., Poh, P., \& Lobinski, R. (2011). Bioaccessibility of essential elements from white cheese, bread, fruit and vegetables. Talanta, 86(30), 425-428. http://dx.doi.org/10.1016/j.talanta.2011.08.049.

Castillejos-Alegría, A. E., \& Porte-Morales, M. J. (1997.) Artisanal sauce of habanero pepper added with pineapple. Chiapas: University of Sciences and Arts of Chiapas.

Chávez-Servia, J. L., Vera-Guzmán, A. M., Carrillo-Rodríguez, J. C. \& Heredia-García, E. (2016). Variation in mineral content in fruits of native varieties of chili (Capsicum annuum L.), grown in the greenhouse. Vitae, 23(1), 48-57.

Elinge, C. M. A., Muhammad, A., Atiku, F. A., Itodo, A. U., Peni, I. J., Sanni, O. M. \& Mbongo, A. N. (2012). Proximate, mineral and antinutrient composition of pumpkin (Curcurbita pepo L) seeds extract. International Journal of Plant Research, 2(5), 146-150.

Elloumi, N., Belhaj, D., Jerbi, B., Zouari, M., \& Kallel, M. (2016). Effects of sewage sludge on bio-accumulation of heavy metals in tomato seedlings. Spanish Journal of Agricultural Research, 14(4), e0807. http://dx.doi.org/10.5424/sjar/2016144-9210. 
European Union - EU. (2006). Setting maximum levels for certain contaminants in foodstuffs (Commission Regulation (EC)-1881). Brussell: EU.

Fisher, A. B. (2005). Heavy metals in the food Chain-Lead, Cadmium and Mercury in foodstuff and population exposures. ProceedingsIndian National Science Academy Part B, 71(3-4), 109-143.

Fleck, H. (1976). Introduction to Nutrition. New York: Publshing Co, Inc.

Flores, P., López, A., Fenoll, J., Hellín, P., \& Kelly, S. (2013). Classification of organic and conventional sweet peppers and lettuce using a combination of isotopic and bio-markers with multivariate analysis. Journal of Food Composition and Analysis, 31(2), 217-225. http:// dx.doi.org/10.1016/j.jfca.2013.05.015.

Food and Agriculture Organization - FAO. World Health Organization - WHO. (1995). General CODEX standard for contaminants and toxins in food and feed (CODEX-STAN 193-1995). Rome: FAO.

Gómez-Rincón, E., Reyes-Vazquez, N., Ramírez-Sucre, M., \& RodríguezBuenfil, I. (2018). Antioxidant activity and its correlation with colorimetric parameters of Capsicum chinense Jacq dried by two methods. Journal of the Graduate Center of the Technological Institute of Merida, 33, 38-42.

Guzmán, I., \& Bosland, P. W. (2017). Sensory properties of chili pepper heat and its importance to food quality and cultural preference. Appetite, 117, 186-190. http://dx.doi.org/10.1016/j.appet.2017.06.026. PMid:28662907.

He, H., Li, Y., \& He, L. F. (2019). Aluminum toxicity and tolerance in Solanaceae plants. South African Journal of Botany, 123, 23-29. http://dx.doi.org/10.1016/j.sajb.2019.02.008.

Herman-Lara, E., Bolívar-Moreno, D., Toledo-López, V. M., CuevasGlory, L. F., Lope-Navarrete, M. C., Barrón-Zambrano, J. A., DíazRivera, P., \& Ramírez-Rivera, E. J. (2019). Minerals multi-element analysis and geographical origin of artisanal goat cheeses. Journal of Food Science and Technology, 39(Suppl. 2), 517-525. http://dx.doi. org/10.1590/fst.23918.

Ibrahim, E., \& Mehanna, N. M. (2015). Determination of some minerals and trace elements content in Domiati cheese by ICP-MS after microwave digestion. Indian Journal of Dairy Science, 68(4), 334-340. http://epubs.icar.org.in/ejournal/index.php/IJDS/article/ view/46487/21688

Ikpeme, C. E., Henry, P., \& Augustine-Okiri, O. (2014). Comparative evaluation of the nutritional, phytochemical and microbiological quality of three pepper varieties. Journal of Food and Nutrition Sciences, 2(3), 74-80. http://dx.doi.org/10.11648/j.jfns.20140203.15.

Ionete, R. E., Dinca, O. R., Geana, E. I., \& Costinel, D. (2016). Macroand microelements as possible markers of quality and authenticity for fruits and derived products. Progress of Cryogenics and Isotopes Separation, 19(1), 54-74.

Khan, M., Jamil-Ahmed, M., \& Ali-Shah, S. Z. (2019). Comparative analysis of mineral content and proximate composition from chili pepper (Capsicum annuum L.) germplasm. Pure and Applied Biology, 8(2), 1338-1347. http://dx.doi.org/10.19045/bspab.2019.80075.

Khanlari, Z. V., \& Jalali, M. (2008). Concentrations and chemical speciation of five heavy metals $(\mathrm{Zn}, \mathrm{Cd}, \mathrm{Ni}, \mathrm{Cu}$, and $\mathrm{Pb}$ ) in selected agricultural calcareous soils of Hamadan Province, western Iran. Archives of Agronomy and Soil Science, 54(1), 19-32. http://dx.doi. org/10.1080/03650340701697317.

Komárek, M., Vaněk, A., \& Ettler, V. (2013). Chemical stabilization of metals and arsenic in contaminated soils using oxides-a review. Environmental Pollution, 172, 9-22. http://dx.doi.org/10.1016/j. envpol.2012.07.045. PMid:22982549.
Materska, M., \& Perucka, I. (2005). Antioxidant activity of the main phenolic compounds isolated from hot pepper fruit (Capsicum annuum L.). Journal of Agricultural and Food Chemistry, 53(5), 1750-1756. http://dx.doi.org/10.1021/jf035331k. PMid:15740069.

Mexico, Secretaria de Salud. (2010). NOM-243-SSA1: Leche, fórmula láctea, producto lácteo combinado y derivados lácteos. Disposiciones y especificaciones sanitarias - métodos de prueba. Norma Oficial Mexicana.

Mexico, Secretaria de Salud. (2017). NOM-189-SCFI: Chile habanero de la Península de Yucatán (Capsicum Chinense Jacq.) - especificaciones y métodos de prueba. Norma Oficial Mexicana.

Moreno-Rojas, R., Sánchez-Segarra, P. J., Cámara-Martos, F., \& AmaroLópez, M. (2010). Multivariate analysis techniques as tools for categorization of Southern Spanish cheeses: nutritional composition and mineral content. European Food Research and Technology, 231(6), 841-851. http://dx.doi.org/10.1007/s00217-010-1338-z.

Nagajyoti, P. C., Lee, K. D., \& Sreekanth, T. V. M. (2010). Heavy metals, occurrence and toxicity for plants: a review. Environmental Chemistry Letters, 8(3), 199-216. http://dx.doi.org/10.1007/s10311-010-0297-8.

Navarro-Alarcon, M., \& Cabrera-Vique, C. (2008). Selenium in food and the human body: a review. The Science of the Total Environment, 400(1-3), 115-141. http://dx.doi.org/10.1016/j.scitotenv.2008.06.024. PMid:18657851.

Oney-Montalvo, J. E., Morozova, K., Ferrentino, G., Ramirez-Sucre, M. O., Rodriguez-Buenfil, I. M., \& Scapicchio, M. (2021). Effects of local environmental factors on the spiciness of habanero chili peppers (Capsicum chinense Jacq.) by coulometric electronic tongue. European Food Research and Technology, 247, 101-110.

Oney-Montalvo, J., Uc-Varguez, A., Ramírez-Rivera, E., Ramírez-Sucre, M., \& Rodríguez-Buenfil, I. (2020a). Influence of soil composition on the profile and content of polyphenols in habanero peppers (Capsicum chinense Jacq.). Agronomy, 10(9), 1234. http://dx.doi. org/10.3390/agronomy10091234.

Pérez-López, A. J., Núñez-Delicado, E., López-Nicolas, J. M., Amor, F. M. D., \& Carbonell-Barrachina, A. A. (2007). Effects of agricultural practices on color, carotenoids composition, and minerals contents of sweet peppers, cv. Almuden. Journal of Agricultural and Food Chemistry, 55, 8158-8164. http://dx.doi.org/10.1021/jf071534n.

Qin, J., Shi, A., Mou, B., Grusak, M. A., Weng, Y., Ravelombola, W., Bhattarai, G., Dong, L., \& Yang, W. (2017). Genetic diversity and association mapping of mineral element concentrations in spinach leaves. BMC Genomics, 18(1), 941. http://dx.doi.org/10.1186/s12864017-4297-y. PMid:29202697.

Ramírez-Sucre, M. O., Baeza-Melchor, T., Echevarria, I., \& RodríguezBuenfil, I. M. (2018). Quality of habanero chili by texture measurements: fresh-cut and post-harvest study. Journal of Food, Nutrition and Population Health, 2, 49-50.

Rodríguez Buenfil, I. M., Ramirez Sucre, M. O., \& Ramirez Rivera, E. D. J. (2020). Metabolómica y cultivo del Chile Habanero (Capsicum Chinense Jacq) de la Península de Yucatán. Mérida: Centro de Investigación y Asistencia en Tecnología y Diseño del Estado de Jalisco, A.C..

Rubio, C., Hardisson, A., Martín, R., Báez, A., Martín, M., \& Álvarez, R. (2002). Mineral composition of the red and green pepper (Capsicum annuum) from Tenerife Island. European Food Research and Technology, 214(6), 501-504. http://dx.doi.org/10.1007/s00217-002-0534-x.

Servicio de Información Agroalimentaria y Pesquera - SIAP. (2020). Producción anual agrícola. Servicio de Información Agroalimentaria y Pesquera. Retrieved from http://infosiap.siap.gob.mx:8080/ agricola_siap_gobmx/ResumenDelegacion.do 
Sevgi-Kirdar, S., Kose, S., Gun, I., Ocak, E., \& Kursun, O. (2015). Do consumption of Kargi Tulum cheese meet daily requirements for minerals and trace elements. Mljekarstvo/Dairy, 65(3), 203-209.

Shintu, L., \& Caldarelli, S. (2006). Toward the determination of the geographical origin of emmental(er) cheese via high resolution MAS NMR: a preliminary investigation. Journal of Agricultural and Food Chemistry, 54(12), 4148-4154. http://dx.doi.org/10.1021/ jf060532k. PMid:16756340.

Solleiro-Rebolledo, J. L. \& Mejía-Chávez, A. O. (2018). The habanero pepper (Capsicum chinense). Tecnoagro, 123.

Taghlidabad, R. H., \& Sepehr, E. (2018). Heavy metals immobilization in contaminated soil by grape-pruning-residue biochar. Archives of Agronomy and Soil Science, 64(8), 1041-1052. http://dx.doi.org/10 $.1080 / 03650340.2017 .1407872$.

Tchounwou, B. P., Yedjou, C. C., Patlolla, A. K., \& Sutton, D. J. (2012). Heavy metals toxicity and the environment. Molecular, Clinical and Environmental Toxicology, 101, p. 133-164.

Wadood, S. A., Boli, G., Xiaowen, Z., Hussain, I. M., \& Yimin, W. (2020). Recent development in the application of analytical techniques for the traceability and authenticity of food of plant origin. Microchemical Journal, 152, 104295. http://dx.doi.org/10.1016/j.microc.2019.104295.
Wang, S., Wu, W., Liu, F., Liao, R., \& Hu, Y. (2017). Accumulation of heavy metals in soil-crop systems: a review for wheat and corn. Environmental Science and Pollution Research International, 24(18), 15209-15225. http://dx.doi.org/10.1007/s11356-017-8909-5. PMid:28455572.

Wang, Y. D., Wang, X., \& Wong, Y. S. (2012). Proteomics analysis reveals multiple regulatory mechanisms in response to selenium in rice. Journal of Proteomics, 75(6), 1849-1866. http://dx.doi.org/10.1016/j. jprot.2011.12.030. PMid:22236520.

Wuana, R. A., \& Okieimen, F. E. (2011). Heavy metals in contaminated soils: a review of sources, chemistry, risks and best available strategies for remediation. International Scholarly Research Network, 2011, 402647.

Zamacona-Ruiz, M., Ramírez-Sucre, M. O., \& Rodríguez-Buenfil, I. M. (2018). Comparison of two extraction and drying methods for the quantification of carotenoids in habanero pepper. Journal of the Graduate Center of the Technological Institute of Merida, 33, 65-68.

Zou, Y., Ma, K., \& Tian, M. (2015). Chemical composition and nutritive value of hot pepper seed (Capsicum annuum) grown in Northeast Region of China. Food Science and Technology, 35(4), 659-663. http://dx.doi.org/10.1590/1678-457X.6803. 